\title{
Institutional Entrepreneurship Pemuda dalam Mengembangkan Pokdarwis Desa Wisata Nglanggeran
}

\begin{abstract}
ABSTRAK
Tulisan ini merupakan hasil penelitian tentang peran institutional entrepreneurship (kewiralembagaan) pemuda dalam mendorong terbentuknya kelompok sadar wisata pada masyarakat Desa Nglanggeran. Kehadiran wisatawan di destinasi wisata pedesaan telah membuka peluang dan tantangan untuk dihadapi secara tepat dan menguntungkan semua yang terlibat di Desa Wisata Nglanggeran. Sering terjadi dengan adanya destinasi wisata, maka masyarakat menggunakan kesempatan itu untuk meningkatkan pendapatan dengan adanya kegiatan pariwisata tersebut. Pembentukan sebuah lembaga sangat penting sebagai wadah masyarakat untuk mengelola dan mengatur fungsi-fungsi pelaksanaan kegiatan kepariwisataan sehingga terwujud mekanisme yang teratur, jelas, dan kuat. Peneliti menggunakan jenis penelitian kualitatif yang bertujuan untuk mendeskripsikan dan menganalisa mengenai Institutional Entrepreneurship Pemuda dalam Mengembangkan Pokdarwis Desa Wisata Nglanggeran. Unit analisis dari penelitian ini adalah kelompok sadar wisata Desa Wisata Nglanggeran. Informan dari penelitian ini merupakan masyarakat atau aktor dalam pembentukan desa wisata dan kelompok sadar wisata. Teknik pengumpulan data yang digunakan adalah wawancara mendalam (indepth interview), observasi, dan dokumentasi. Teori yang digunakan untuk menganalisis adalah teori pembentukan kelompok yang dicetuskan oleh Wheelan dan Kewiralembagaan yang digagas oleh DiMaggio dan disempurnakan oleh Kusworo. Hasil penelitian menunjukkan bahwa pemuda yang dimotori oleh Sugeng Handoko berhasil memberdayakan masyarakat Desa Nglanggeran untuk aktif dalam pembentukan desa wisata sehingga masyarakat dapat mengambil manfaat yang didapatkan dari kegiatan kepariwisataan. Masyarakat dilibatkan dalam musyawarah, menyelesaikan permasalahan serta menentukan rencana pengembangan Desa Nglanggeran sebagai desa wisata langkah yang ditempuh adalah membangun struktur pengelolaan kelompok dan menciptakan jejaring kerja sama dengan stakeholder. Pengembangan Desa Wisata Nglanggeran memiliki dinamika, mulai dari munculnya aktor, berkembangnya jaringan, hingga prestasi. Dinamika tersebut berdampak positif pada pengembangan desa wisata.

Kata kunci : Kewiralembagaan, Desa Wisata, Pokdarwis Nglanggeran
\end{abstract}

\begin{abstract}
This article is a result of research on the role of Institutional Entrepreneurship to encourage the formation group of tourism awareness to Nglanggeran village's society. The presence of tourists in rural tourist destination has opened opportunities and challenges to deal appropriately and benefit all those involved in tourist village of Nglanggeran. Often happens in tourist destination, the society use that occasion to increase their income of the tourism activities. The formation of institution is very important as a container of society to manage and regulate the functions of the implementation of tourism activities so that materialize mechanism which is regularly, clear, and strong. Researcher is using qualitative research to describe and analyze the dynamic of tourism awareness group establishment in Desa Wisata Nglanggeran. The unit analysis from this research was group itself. The informant was the people who create the rural tourism destination and the tourism awareness group. The data was collected through in depth interview, observation and documentation. Which overall analysis is using the theory of Wheelan about Group Formation Theory and DiMagio and completed by Kusworo about Institutional Entrepreneurship.Result of this research shows that Sugeng Handoko succeed on including
\end{abstract}


people of Nglanggeran to be active on creating the rural tourism area/destination, so that the people could get the benefit from the tourism itself. The people are participating on consultative meeting, problem solving and planning. These actions are followed up by creating the structure of the group and cooperation with the stakeholders to build Desa Wisata Nglanggeran. The dynamic happened before and until the research was done. During the amount of time, it gives the positive impact of Desa Wisata Nglanggeran which could be seen from the group from the people, network and achievements.

Keywords : Institutional Entrepreneurship, Tourism Village, Pokdarwis Nglanggeran

\section{DESA WISATA SEBAGAI UPAYA PEMBANGUNAN DAN KESEJAHTERAAN}

Pembangunan nasional merupakan salah satu usaha yang dilakukan oleh pemerintah untuk meningkatkan kesejahteraan masyarakat. Indikator yang paling mudah untuk digunakan dalam mengukur kesejahteraan masyarakat adalah dari segi pertumbuhan ekonominya. Salah satu bentuk usaha pemerintah dalam usaha meningkatkan pertumbuhan ekonomi adalah dengan program pemberdayaan masyarakat. Program pemberdayaan masyarakat ini dibuat oleh pemerintah dengan tujuan agar masyarakat menjadi lebih mandiri. Salah satu program pemberdayaan yang dilakukan oleh pemerintah adalah desa wisata.

Desa Wisata merupakan program dari Kementerian Pariwisata dan Ekonomi Kreatif. Desa Wisata adalah salah satu agenda dalam Program Nasional Pemberdayaan Masyarakat (PNPM) Mandiri diluncurkan pemerintah pada tahun 2009. Peraturan Menteri Kebudayaan Dan Pariwisata Nomor: PM.26/UM.001/MKP/2010 menyebutkan bahwa PNPM Mandiri Desa Wisata bertujuan untuk penanggulangan kemiskinan yang ditujukan kepada masyarakat desa wisata, masyarakat di sekitar daya tarik wisata, dan masyarakat di sekitar usaha pariwisata. Atas dasar tersebut, diperlukan suatu upaya untuk kelompok masyarakat dapat memberdayakan masyarakat sekitar destinasi wisata. Berkembangnya desa wisata ini tidak lepas dari kelompok sadar wisata yang melakukan pemberdayaan kepada masyarakat sekitar. Melalui pemberdayaan tersebut masyarakat sekitar merasakan manfaat yang positif dari keberadaan desa wisata.

Industri pariwisata nasional saat ini sedang mengalami perkembangan yang sangat cepat dan pertumbuhan akan semakin besar dalam tahun-tahun mendatang (Kusworo, 2000). Website resmi Pemerintah Indonesia di www.indonesia.go.id memuat pernyataan Wakil Menteri Pariwisata dan Ekonomi Kreatif, Sapta Nirwandar, mengenai pertumbuhan industri pariwisata di Indonesia tahun 2014 mencapai 9,39 persen, lebih tinggi dari tahun sebelumnya. Angka tersebut di atas pertumbuhan ekonomi nasional yang mencapai 5,7 persen. Kondisi seperti ini didukung banyaknya fasilitas yang mendukung dalam melakukan perjalanan wisata dengan pembangunan berbagai kebijakan pemerintah, swasta, maupun masyarakat sekitar. Oleh sebab itu, pariwisata merupakan sektor yang menjanjikan dalam peningkatan ekonomi suatu daerah maupun masyarakat setempat di destinasi wisata. Pertumbuhan tersebut dapat berpengaruh terhadap tingkat kesejahteraan masyarakat sekitar. 
Mengutip Kusworo (2009), pariwisata pedesaan sebagai model baru dikenal sebagai pariwisata minat khusus (special interest tourism) yang memberikan peluang bagi perkembangan Obyek dan Daya Tarik Wisata (ODTW) yang berbasis masyarakat. Jenis wisata alternatif dipandang lebih menyandarkan pada minat khusus dengan mengutamakan persinggungan penduduk dan budaya lokal. Bila berbicara mengenai wisata pedesaan, akan erat kaitannya dengan desa wisata. Damanik (2013) mengatakan bahwa konsep pariwisata pedesaan dimaknai sebagian keseluruhan aktivitas wisata yang memanfaatkan sumber daya (alam, budaya, dan buatan) pedesaan sebagai objek dan daya tarik pariwisata. Yogyakarta merupakan salah satu provinsi di Indonesia yang berhasil dalam pengembangan desa wisata. Data Dinas Pariwisata DIY mencatat pada tahun 2011 terdapat 104 desa wisata, 45 diantaranya mendapatkan bantuan dari pemerintah melalui Program PNPM Pariwisata. Desa wisata yang berjumlah 104 yang ada di DIY, 18 diantaranya terdapat di Kabupaten Gunungkidul.

Banyak desa di Yogyakarta memiliki sisi keunikan yang tak dapat ditemui di daerah lain. Salah satu desa wisata yang banyak menarik minat wisatawan domestik dan mancanegara adalah Desa Wisata Nglanggeran di Kabupaten Gunung Kidul. Kabupaten Gunung Kidul menyimpan keindahan alam dan potensi pariwisata beragam. Desa Wisata Nglanggeran menawarkan keindahan Kawasan Ekowisata Gunung Api Purba dan Embung Nglanggeran. Selain itu, atraksi wisata yang ditawarkan berupa kegiatan perkemahan, kegiatan malam keakraban, outbond, kegiatan live in, flying fox, wisata budaya seni tari, dan seni karawitan.

Adanya peningkatan jumlah kunjungan ke Desa Wisata Nglanggeran, maka pengelolaan objek wisata alam secara profesional dan baik memungkinkan untuk berkembangnya kegiatan kepariwisataan yang memberikan dampak positif bagi masyarakat sekitar (Suwantoro,1997). Kehadiran wisatawan di destinasi wisata pedesaan telah membuka peluang dan tantangan untuk dihadapi secara tepat dan menguntungkan semua yang terlibat di dalamnya. Keberadaan destinasi wisata merupakan peluang bagi masyarakat untuk meningkatkan pendapatan.

Desa Wisata Nglanggeran dan Kelompok Sadar Wisata Nglanggeran pernah mendapat Juara 2 Penghargaan Desa Wisata yang diberikan oleh pemerintah. Penghargaan yang diterima pada tahun 2013 tersebut menjadi bukti keberhasilan desa wisata tersebut dalam membentuk lembaga sosial. Keberhasilan tersebut tidak lepas dari aktor-aktor yang mendukung dalam pembentukan kelompok sadar wisata (Kompas.com, 2013).

Desa Wisata Nglanggeran mampu bertahan dan semakin berkembang karena didukung oleh keberadaan kelompok sadar wisata sebagai institusi dan wadah utama yang beranggotakan masyarakat sekitar. Kelompok sadar wisata ini berperan penting dalam mempertahankan eksistensi dan mengembangkan Kawasan Ekowisata Gunung Api Purba dan Embung Nglanggeran. Prinsip kerjasama dan modal sosial yang dimiliki oleh setiap anggota berhasil menarik minat wisatawan untuk berkunjung.

Ketika membangun lembaga sosial, masyarakat Desa Nglanggeran dihadapkan pada tantangan berupa homogenitas masyarakat, terutama latar belakang 
penghidupan sebagai petani bukan sebagai penyedia jasa pariwisata. Selain itu, destinasi wisata Kawasan Ekowisata Gunung Api Purba dan Embung Nglanggeran berada di tiga dusun padahal harus melibatkan masyarakat satu desa yang terdiri dari enam dusun. Penelitian ini berfokus pada bagaimana inisiator dapat membentuk kelompok pemberdayaan masyarakat dalam kondisi masyarakat yang homogen. Melalui proses panjang, masyarakat berhasil membentuk kelompok sadar wisata yang terstruktur sehingga dapat memberdayakan masyarakat. Hasilnya tidak hanya dinikmati inisiator itu sendiri, tetapi seluruh masyarakat Desa Nglanggeran. Maka dari itu, penting untuk meneliti proses pembentukan Kelompok Sadar Wisata Desa Wisata Nglanggeran. Penulis tertarik mengkaji peran pemuda dalam mengembangkan Pokdarwis Desa Wisata Nglanggeran

\section{DINAMIKA PEMBENTUKKAN KELOMPOK SADAR WISATA DESA NGLANGGERAN}

Pengembangan kawasan ekowisata Gunung Api Purba dilakukan oleh Karang Taruna Bukit Putra Mandiri di Desa Nglangeran sejak tahun 1999. Kegiatan karang taruna ini mengarah pada kepedulian lingkungan. Beberapa kegiatannya adalah menggerakkan masyarakat untuk melakukan reboisasi di Gunung Api Purba serta konservasi pohon aren. Belum ada kegiatan yang bersifat bisnis namun karangtaruna dan warga terbukti mampu bekerjasama sehingga pemerintah Desa Nglanggeran mempercayakan pengelolaan lahan seluas 48 hektar kepada pemuda (Karang Taruna Bukit Putra Mandiri). Kebijakan tersebut tertuang dalam SK Kepala Desa
Nglanggeran No.05/KPTS/1999 tertanggal 12 Mei 1999.

Pokdarwis Desa Wisata Nglanggeran terbentuk dari adanya PNPM Pariwisata tahun 2010. Pada tahun tersebut masyarakat mendapatkan sosialisasi pembuatan proposal PNPM Pariwisata. Ini ditindaklanjuti dengan bergabungnya Pokdarwis Nglanggeran dalam Tim PNPM Pariwisata Dinas Kebudayaan Pariwisata Kabupaten Gunung Kidul. Sugeng Handoko, salah satu tokoh pemuda, terpilih mewakili Desa Nglanggeran sebagai fasilitator PNPM Pariwisata.

$\begin{array}{ccc}\text { Desa } & \text { Wisata } & \text { Nglanggeran } \\ \text { mendapatkan } & \text { pendanaan } & \text { dari PNPM }\end{array}$ Pariwisata berupa kegiatan pendampingan dan pelatihan bagi anggota Pokdarwis dan masyarakat sekitar. Kegiatannya meliputi teknik sosialisasi, penggalian gagasan, rembug warga, perancangan program kerja, pelaksanaan hingga proses pelaporan. Konsep utama yang diusung PNPM Pariwisata adalah pemberdayaan masyarakat untuk kesejahteraan, sejalan dengan pengembangan Desa Wisata Nglanggeran.

Selain pendanaan dari PNPM Pariwisata, pengelola Gunung Api Purba mendapatkan suntikan dana dari pihak swasta, yaitu Bank Mandiri, Bank BRI, PT Pertamina, dan BPD. Selain itu, Gubernur DIY memberikan dana hibah untuk membangun dan mengembangkan kebun buah di sekitar Embung Nglanggeran untuk mendukung keberagaman atraksi wisata yang dijual. Dua tahun paska dibangunnya kebun buah, dikembangkan wisata Embung Nglanggeran yang sekaligus berfungsi sebagai tadah air hujan sarana irigasi lahan pertanian di Desa Nglanggeran. Saat ini Pokdarwis Desa Wisata Nglanggeran mempunyai media promosi dengan menggunakan leaflet, website 
(www.gunungapipurba.com), Facebook, Instagram, dan akun resmi Blackberry Massanger. Wisata ini sudah mulai dikenal oleh masyarakat luas di seluruh Indonesia.

Pengurus Pokdarwis Nglanggeran bekerja keras supaya dapat melestarikan lingkungan dan meraih nilai ekonomis keberadaan wisata. Saat ini perkembangan kualitas destinasi wisata dikawasan Ekowisata Nglanggeran secara umum dapat dikatakan baik. Dukungan masyarakat semakin meningkat, jumlah pengunjung dan lama tinggal semakin bertambah serta dampak ekonomi yang dirasakan masyarakat semakin meluas.

Harapan dulu ketika awal merintis hanya tujuanutama, yaitu melindungi alam dan memberikan kegiatan positif ke pemuda. Ketika sudah naik jenjang harapannya ingin mencoba melibatkan tidak hanya pemuda tetapi kepada kelompok lain. Dan ketika harapan itu terwujud mungkin punya harapan kedepannya lagi yaitu semua dusun di Desa Nglanggeran dapat mengambil segi ekonomi di kegiatan kepariwisataan.

(Wawancara dengan Sugeng Handoko tanggal 21 Juni 2015)

Sugeng Handoko sebagai aktor inovatif, inisiator kelompok sadar wisata, sekaligus sebagai fasilitator PNPM Pariwisata, mempunyai peran penting dalam pengembangan destinasi wisata Gunung Api Purba Nglanggeran. Ia berhasil merangkul masyarakat untuk turut serta dalam pengelolaan desa wisata. Ini juga tidak lepas dari peran sektor swasta melalui program CSR (Corporate Social Responsibility). Dana-dana tersebut dihimpun untuk kegiatan peningkatan kapasitas dan fasilitasi kelompok. Meskipun demikian, pengelolaan Kelompok Sadar Wisata Desa Nglanggeran dilakukan secara mandiri oleh masyarakat. Tidak bergantung pada pihak manapun.

\section{TAHAPAN PEMBENTUKAN KELOMPOK SADAR WISATA}

Pembentukan Kelompok Sadar Wisata Nglanggeran diwarnai dengan penokohan masyarakat terhadap aktor. Anggota pokdarwis atau masyarakat lebih percaya dengan pemimpin kelompok yang membentuk desa wisata. Ini karena masyarakat percaya terhadap kemampuan dalam menggerakkan masyarakat, tingkat pendidikan, rekam jejak yang baik serta tanggung jawab aktor. Kepercayaan terhadap aktor menjadi kunci keberhasilan pembentukan pokdarwis.

Meskipun demikian, pembentukan kelompok sadar wisata dihadapkan pada berbagai tantangan. Perbedaan pendapat antar warga menjadi tantangan utama. Kondisi ini dapat diselesaikan dengan masih kentalnya nilai-nilai musyawarah mufakat dalam kehidupan bermasyarakat.

Pembagian peran menjadi kunci penting di dalam mengantisipasi perselisihan di antara anggota. Pengurus membagi peran sesuai dengan kapasitas masing-masing warga ke dalam kelompokkelompok, yaitu kelompok pemandu wisata, kelompok sanggar kerajinan, kelompok seni budaya, kelompok makanan khas, kelompok homestay, kelompok jasa fotografi, dan kelompok jasa penyewaan tenda. Adanya pembagian peran ini terbukti mampu menjadikan pengelolaan kelompok sadar wisata terstruktur dan efektif.

Masyarakat dengan homogenitas, usia, latar belakang keluarga berbeda-beda. Jadi misalnya kita menginformasikan A belum tentu ditangkap A. Pemerataan secara pemahaman masyarakat berbeda-beda, kita belum punya formulasi untuk mengatur misalnya kita punya 80-an homestay itu tidak akan giliran kita pakai karena fasilitas dan keinginan wisatawan berbeda jadi kecemburuan masyarakat masih ada. 
(Wawancara dengan Sugeng Handoko Pengelola Pokdarwis pada tanggal 21 Juni 2015)

Kelompok Sadar Wisata mengelola konflik yang muncul pada kegiatan kepariwisataan. Hal tersebut dapat melapangkan jalan bagi kelompok sadar wisata untuk menempuh tahap-tahap perkembangan selanjutnya. Hal terpenting pada tahap berjuang melawan ketergantungan adalah mempertemukan berbagai kepentingan yang muncul dalam kelompok. Maka akomodasi kepentingan semua unsur kelompok merupakan langkah penting dalam menyelamatkan kelompok dari perpecahan. Termasuk dalam hal ini adalah membina komunikasi dengan kepentingan yang ada dilingkungan kelompok. Artinya kelompok harus mau mendengarkan 'suara' dari semua elemen agar mampu membina solidaritas kelompok yang dilakukan pada tahap ketiga yaitu tahap membina kepercayaan dan struktur (trust and structure).

Paling sulit menengahi untuk SDM, karena adanya perbedaan presepsi, namum masyarakat selalu memberikan respon yang baik, karna respon yang baik adalah dukungan yang luar biasa.

(Wawancara dengan Bapak Wagiran Tokoh Masyarakat Desa Nglanggeran Tanggal 16 Juni 2015)

Setiap 35 hari sekali kelompok sadar wisata Nglanggeran mengadakan pertemuan di Pendopo Kalisong. Pertemuan tersebut membahas apa yang menjadi planning kedepannya, evaluasi 35 hari yang lalu, dan membahas masalahmasalah serta ide gagasan masyarakat yang akan dikaji lebih lanjut. Ketika ada permasalahan dengan anggota pokdarwis maupun masyarakat dibahas dan dipecahkan melalui musyawarah mufakat. Kepercayaan masyarakat terhadap stakeholder pembentukan kelompok sadar wisata sangat tinggi dengan cara memberikan respon yang tinggi seperti yang diungkapkan Bapak Wagiran sebagai sesepuh Desa Nglanggeran yang aktif dalam kegiatan kelompok sadar wisata. Kepentingan semua unsur pokok kelompok sadar wisata dalam menengahi konflik merupakan langkah penting dalam menyelamatkan kelompok dari perpecahan. Kelompok sadar wisata Nglanggeran lebih matang dalam bernegosiasi dengan pihak ketiga maupun pemerintah. Strategi yang dibuat oleh pengelola maupun inisiator untuk menjaring wisatawan untuk kegiatan live in dengan cara membuat penawaran proposal kegiatan untuk disebar ke instansi maupun sekolah-sekolah baik SMP maupun SMA. Peran maupun pembagian tugas kepada kelompok yang berada dibawah naungan pokdarwis lebih terbuka dan berorientasi tugas. Hubungan yang terjadi dalam sebuah kelompok sadar wisata dan kelompokkelompok lain sangat berkesinambungan dan saling kerjasama satu sama lain.

Hubungan antara kelompok Purba Rasa, kelompok tani, dan kelompok sadar wisata hubungannya baik karena berkesinambungan, Selalu Ada komunikasi yang baik hubungan antar anggota, saling mendukung, dan saling kerjasama.

(Wawancara dengan Ibu Rini ketua Kelompok Purba Rasa Desa Nglanggeran Tanggal 17 Juni 2015)

Masyarakat mempunyai keahlihan pada masing-masing bidang mulai bekerja sesuai yang dimiliki individu tersebut. Komunikasi satu arah kepada kelompok lain dan kelompok sadar wisata sebagai lembaga sosial yang menaungi masyarakat 
tersebut terus terjalin. Selain dalam dalam forum 35 hari sekali, komunikasi dan penggasan ide kepada pengelola dilakukan setiap waktu. Jarak yang dekat dan waktu yang tidak terbatas memudahkan anggota kelompok untuk tahap bekerja lebih efektif.

$$
\text { Kelompok sadar wisata }
$$

Nglanggeran terus melakukan inovasiinovasi untuk menunjang bertambahnya keunikan atraksi wisata yang disajikan di Desa Wisata Nglanggeran untuk mencapai prestasi dan tujuan yang diharapkan. Pada fase ini kelompok terus melakukan koordiasi dengan masyarakat Nglanggeran dengan mengadakan forum-forum dan sosialisasi. Pada forum tersebut memuat evaluasi kerja bersama, saling memberi umpan baik, mengekspresikan perasaan masing-masing maupun kelompok. Ini dimaksudkan untuk mengembangkan kemampuan mereka bekerja secara efektif dimasa yang akan datang agar aspirasi dan suara dari masyarakat sebagai host dapat disampaikan kepada pengelola agar terciptanya Desa Wisata yang kondusif dan terstruktur. Struktur organisasi kelompok sadar wisata Nglanggeran sebagai berikut :
Pada struktur organisasi kelompok sadar wisata Nglanggeran, pemerintah daerah yaitu Dinas Pariwisata dan Kebudayaan Kabupaten Gunungkidul sebagai Pembina dan pemerintah desa serta tokoh kunci masyarakat sebagai penasehat kelompok ini. Hal ini membuktikan keberadaan sinergisitas antara pemerintah daerah, pemerintah desa, dan tokoh masyarakat dalam pembentukan kelompok sadar wisata Nglanggeran dan menjalin keharmonisan dalam melakukan pemberdayaan masyarakat.

Kelompok kerja yang dibangun melibatkan beberapa kelompok yang ada di Desa Nglanggeran seperti kelompok PKK, Kelompok Tani, Kelompok Karang taruna, Kelompok sentra pemuda, serta melibatkan perwakilan dari 5 (lima) dusun yang ada di Desa Nglanggeran agar pelibatan masyarakat dapat merata di semua dusun.

\section{Bagan 1. Struktur Organisasi Pokdarwis Nglanggeran}

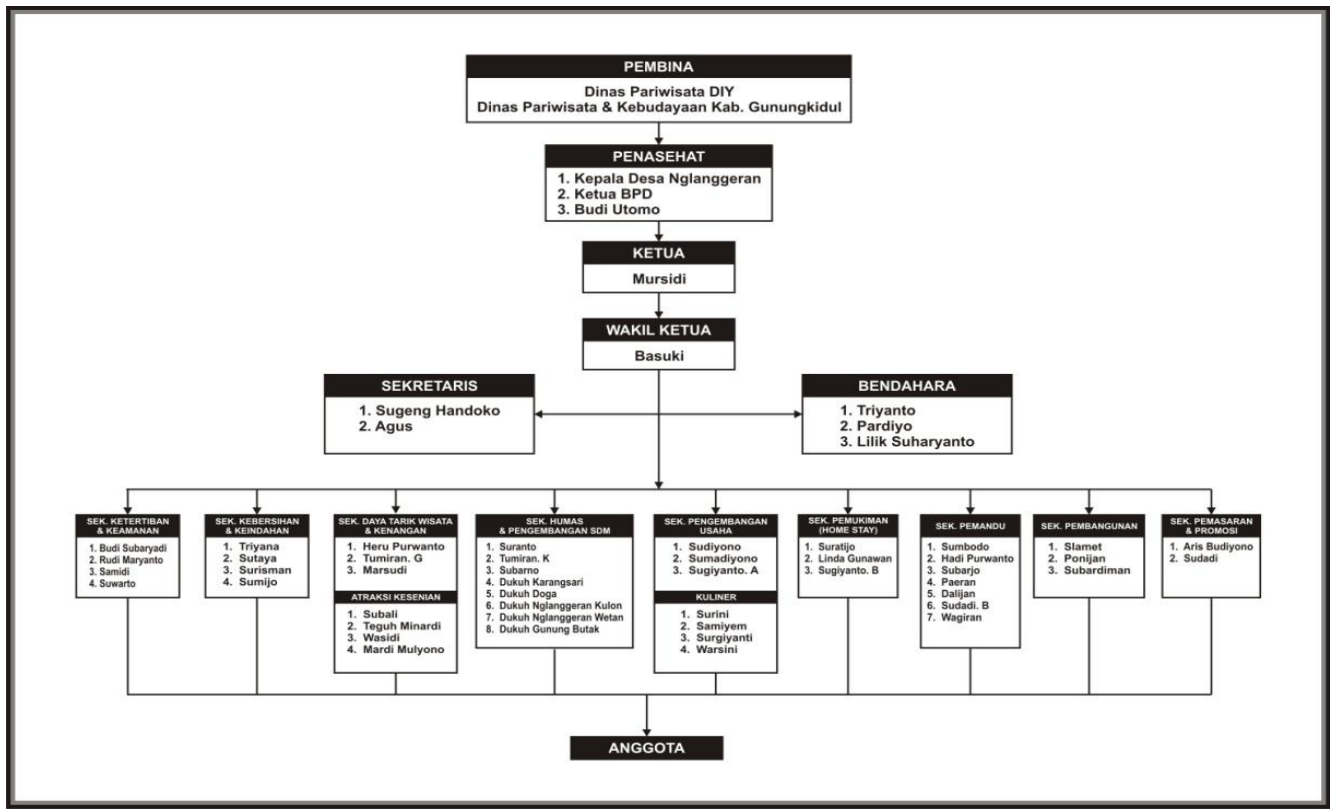

Sumber: Arsip Pokdarwis Nglanggeran. 
PERAN INSTITUTIONAL

\section{ENTREPRENEUR DALAM}

PEMBENTUKAN KELOMPOK SADAR WISATA NGLANGGERAN

Sugeng Handoko, salah seorang pemuda Desa Nglanggeran yang tergerak hatinya untuk menggali potensi alam di desa mereka. Awalnya Beliau mengaku hanya ingin menggerakkan pemuda desa untuk lebih produktif, tetapi kemudian muncul tekad untuk menerapkan pengetahuannya bersama rekan-rekannya secara langsung. Beliau menjelaskan bahwa organisasi mereka ini berbasis masyarakat, yaitu masyarakat juga ikut merasakan hasil dari pariwisata di Gunung Api Purba ini.

Keinginan untuk menjadi desa wisata memang ada tetapi untuk membuat besar belum terpikirkan. Dahulu karangtaruna usaha produktifnya hanya menanam pohon gajah dan pohon pisang. Awalnya dahulu ketika mengikuti HM (himpunan Mahasiswa) mengadakan kegiatan malam keakraban. Karena dahulu semua tempat malam keakraban yang ada di Jogja penuh maka temen-teman saya ajak kesini. Untuk kayu bakar beli disekitar masyarakat dan makan juga pesan dimasyarakat. Ternyata dengan mengelola dengan 80-an peserta hasilnya lebih besar daripada kita menanam mengelola tanaman selama 3 bulan. Kita berfikiran bahwa karang taruna bisa kasnya lebih besar lagi jika ada kegiatan disini. Dengan bantuan internet saat masih zaman friendster, ada yang foto saya yang diupload, akhirnya temanteman saya penasaran dan terus berkembang lebih banyak yang berdatangan serta menanyakan penginapan.

(Wawancara dengan Sugeng Handoko Pengelola Pokdarwis pada tanggal 21 Juni 2015)
Kelompok Sadar Wisata Nglanggeran sebagai organisasi sosial yang berfokus dalam bidang swadaya masyarakat ini, dulunya sempat kurang mendapat perhatian dari pemerintah. Hal ini diakui Sugeng Handoko menjadi masalah utama dalam pengembangan organisasi mereka dan juga khususnya bagi pengelolaan obyek wisata itu sendiri. Namun seiring berjalannya waktu, tempat ini mendapat perhatian dari pemerintah, sehingga terbentuklah organisasi karangtaruna sebagai pengelola wisata Ekowisata Gunung Api Purba Nglanggeran.

Selain itu, tidak jauh dari Gunung Api Nglanggeran, terdapat embung (danau) buatan yang disekitarnya ditanami pohon durian. Embung ini juga sebagai tempat wisata sekaligus konservasi untuk berbagai macam tumbuhan yang ada di sekitarnya. Walaupun masih tahap pengembangan, danau buatan ini sudah cukup ramai dikunjungi oleh wisatawan baik yang berasal dari Jogja maupun dari luar Jogja.

Aktor yang berperan pada proses pembentukan desa wisata dan kelompok sadar wisata dapat dikategorikan sebagai masyarakat desa setempat itu sendiri dan kelompok yang mendukung terjadinya proses pembentukan di luar masyarakat asli desa tersebut. Pada kategori pendukung pembentukan kelompok sadar wisata, termasuk didalamnya adalah Sugeng Handoko sebagai inisiator. Bagan dibawah ini menggambarkan peran aktor dalam pembentukan Desa Wisata Nglanggeran mengadobsi bagan IION. 


\section{Bagan 2. Relasi Aktor dan Struktur Pembentukan Pokdarwis Nglanggeran}

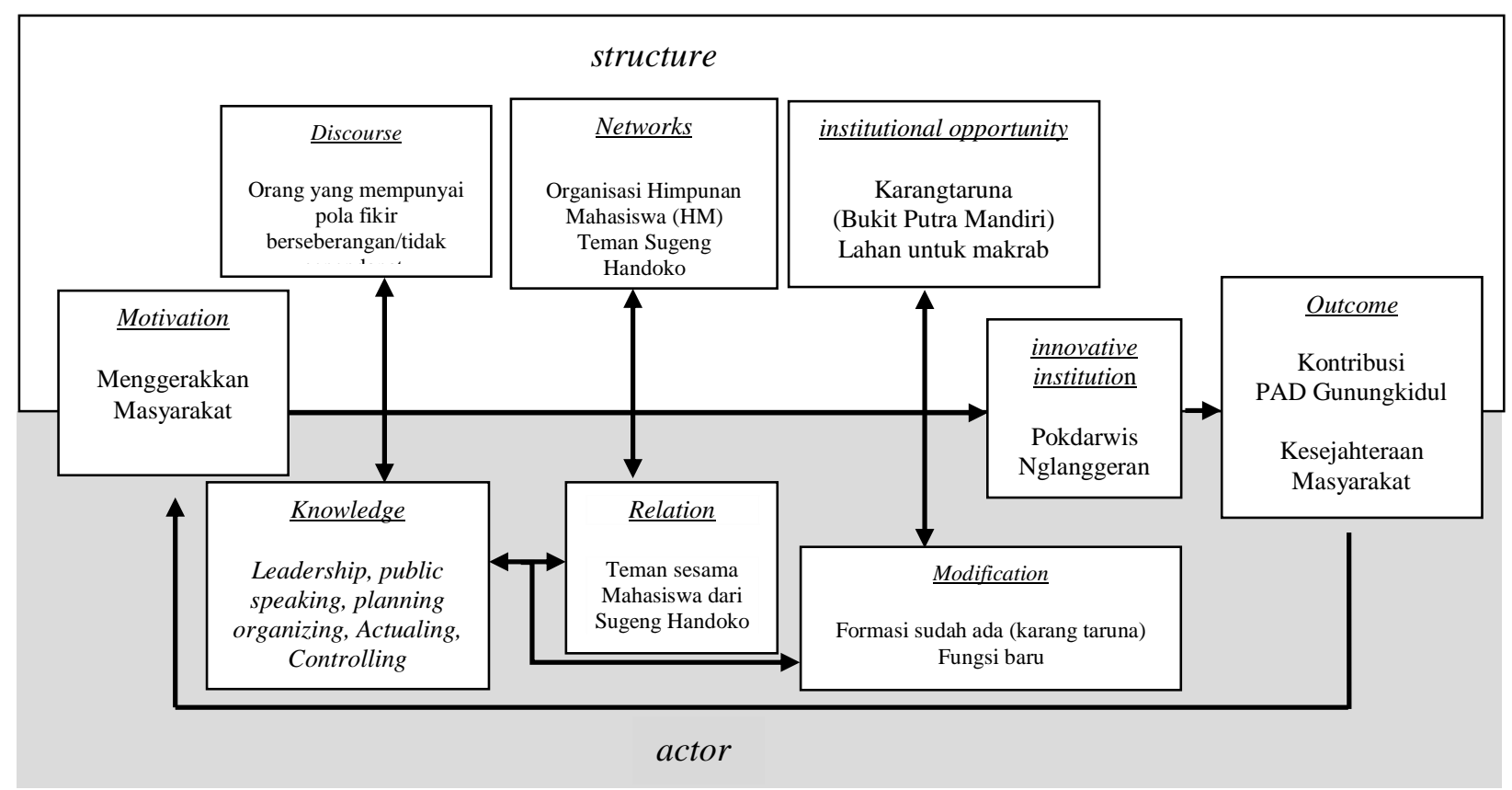

Sumber: Interpretasi Data Menggunakan Bagan IION.

Tahap awal dalam dinamika proses pembentukan kelompok sadar wisata karena aktor memiliki motivasi untuk meggerakkan masyarakat Nglanggeran. Pengetahuan Sugeng Handoko yang didapat dari bangku kuliah berupa pengalaman leadership, public speaking, planning, organizing, actualizing, dan controling. Diskursus dinamika proses pembentukan yang ditemukan dalam penelitan ini adalah terdapat orang yang berseberangan dalam mengemukakan pendapat atau orang yang tidak sepemikiran dengan pengelola. Seperti yang dikemukakan Sugeng Handoko dalam wawancara berikut menjelaskan bahwa isu yang ada dalam proses pembentukan kelompok dengan cara memberikan tugas tanggung jawab kepada masyarakat yang mempunyai pola pikir berseberangan.

Semisal kita mengadakan forum dengan masyarakat yang mempunyai pola fikir yang berseberangan dengan pokdarwis, maka kita menghargai dengan cara memberikan tugas tanggung jawab.

(Wawancara dengan Sugeng Handoko Pengelola Pokdarwis pada tanggal 21 Juni 2015)

Motivasi sebagai titik awal utama kewiralembagaan baik aktor maupun struktur. Asumsi peneliti bahwa aktor dalam pembentukan kelompok sadar wisata termotivasi karena ingin menarik masyarakat berpartisipasi dalam kegiatan kepariwisataan, sebagai wadah penyadaran sapta pesona, dan menghindari konflik yang ada di Desa Wisata Nglanggeran.

Hal ini menjadi isu yang sangat menarik karena dengan pengalaman yang ada, Sugeng Handoko dapat mengatasi permasalahan yang ada dalam dinamika proses pembentukan kelompok sadar wisata. Relasi yang dibangun dengan menyebarluaskan informasi melalui media sosial yang ada kepada mahasiswa lain. Berawal dari teman satu kampus hingga dapat menyebar kepada teman yang lainnya. 
Akan tetapi, network yang melekat pada Sugeng Handoko adalah dari organisasi himpunan mahasiswa yang ada dikampusnya. Sosok Sugeng Handoko sebagai pengurus Himpunan Mahasiswa dapat menjadi kekuatan penuh untuk menyebarluaskan informasi potensi desanya kepada orang-orang yang dikenal atau yang mengalnya. Keempatnya ini saling bersinambungan untuk memodifikasi potensi yang sudah ada di Desa Nglanggeran yang menarik untuk dijadikan tempat wisata dengan formasi yang sudah ada yaitu Karang Taruna Bukit Putra Mandiri.

Pada upaya mencapai tujuan demi tercapainya peningkatan kesejahteraan masyarakat dan mewujudkan lingkungan dan suasana yang kondusif bagi berkembangnya kegiatan kepariwisataan di Desa Wisata Nglanggeran, aktor atau inisiator membutuhkan cara yang inovatif baik dalam penentuan kebijakan maupun pengelolaan kelompok sadar wisata. Caracara tersebut berkaitan erat dengan pengetahuan dan relasi individu serta jaringan, dan diskursus yang disediakan struktur.

Sugeng Handoko menggagas desa wisata ini bermula ketika menjadi Ketua Karang Taruna Bukit Putra Mandiri. Dukungan para anggota karang taruna yang solid untuk memanfaatkan potensi sumber daya alam berupa Gunung Api Purba dan suasana desa sebagai daya tarik wisata. Seiring berjalannya waktu terjadi perkembangan signifikan, sehingga perlu adanya wadah khusus sehingga dibentuk Kelompok Sadar Wisata di tahun 2007.

Anggota pengelola Desa Wisata dan juga pengurus Pokdarwis berasal dari masyarakat sekitar desa wisata. Seperti penuturan Bapak Senen sebagai Kepala Desa Nglanggeran bahwa gebrakan inisiator untuk memberdayakan masyarakat dengan cara mengikutsertakan masyarakat setempat sebagai pengelola.

Awalnya pemuda keluar ke luar kota untuk merantau bahkan ke luar negeri. Gebrakan mas sugeng daripada pergi keluar kota lebih baik mengelola yang ada, banyak pemuda yang direkrut menjadi anggota pokdarwis.

(Wawancara dengan Bapak Senen Kepala Desa Nglanggeran)

Kemudian bersama masyarakat menggagas strategi pemasaran untuk memromosikan desanya juga dipublikasikan melalui blog pribadinya. Ketika dilombakan mendapatkan hadiah juara II Festival Blog Tingkat Nasional 2010 dari 1.027 Peserta se-Indonesia. Blog ini berisi media marketing Kawasan Ekowisata Gunung Api Purba Nglanggeran dengan judul tulisan "Dengan Blog, Potensi Desaku Kutunjukan kepada Dunia".

Melalui program pemberdayaan yang dicanangkan oleh Sugeng Handoko kepada masyarakat, inisiator ini membentuk tim advokasi yang memiliki beberapa tugas, yakni (1) memberikan sosialisasi/memperkenalkan gagasan desa wisata, (2) mengidentifikasi permasalahandan potensi setiap masyarakat, (3) mengakomodasi kebutuhan pelatihan bagi masyarakat dari pihak ketiga, dan (4) mendampingi masyarakat dalam pelaksanaan kegiatan.

Secara bertahap dan terus menerus kelompok sadar wisata selalu meningkatkan kapasitas pengelola seiring dengan perkembangan Desa Wisata. Beberapa pelatihan bagi masyarakat dari berbagai lembaga dan dinas terkait adalah:

a. Pelatihan Pemandu oleh Dinas Pariwisata Kabupaten Gunungkidul dan Dinas Pariwisata DIY

b. Pelatihan Manajemen Objek dan Daya 
Tarik Wisata

c. Pelatihan Kuliner oleh Dinas Pariwisata DIY

d. Pelatihan Bahasa Asing oleh Politeknik API Yogyakarta dan Universitas Sanata Dharma Yogyakarta

e. Pelatihan Penanggulangan Bencana oleh International Organization for Migration (IOM)

f. Pelatihan kesenian, pengelolaan homestay, penyajian kuliner, dll (oleh pengelola dengan dana PNPM Pariwisata)

g. Kelompok kedua adalah pendukung pembentukan desa wisata dan kelompok sadar wisata adalah Corporate Sosial Responsibility (CSR) dari Bank Mandiri, Bank BCA, dan PT. Pertamina. Mereka ikut serta mengembangkan ide kreatif masyarakat melalui pelatihan, workshop, diskusi, dan dukungan dana. Dana tersebut digunakanuntuk kegiatan operasional pelatihan, perbaikan infrastruktur, serta memperbaiki fasilitas yang kurang di Desa Wisata Nglanggeran.

h. Ketiga, pemerintah. Pemerintah ditingkat Kabupaten hingga nasional melaui Dinas Pariwisata berperan memberikan dukungan secara politis untuk menjaga kelangsungan pelaksanaan program melaui dana PNPM Pariwisata.

Kelompok keempat adalah masyarakat Desa Nglanggeran itu sendiri. Kelompok ini dibagi menjadi kelompok sentra pemuda, kelompok karang taruna,

Tabel 1. Penyuluhan/Sosialisasi yang Sudah Dilakukan sebagai Salah Satu Aktivitas Kelompok Sadar Wisata kepada Masyarakat

\begin{tabular}{|l|l|l|l|}
\hline No & \multicolumn{1}{|c|}{$\begin{array}{c}\text { Nama } \\
\text { Kegiatan }\end{array}$} & \multicolumn{1}{|c|}{ Penjelasan/Diskrisi } & Waktu dan Tempat \\
\hline 1. & $\begin{array}{l}\text { Penyuluhan } \\
\text { tentang konsep } \\
\text { Desa Wisata }\end{array}$ & $\begin{array}{l}\text { Memberikan pemahaman } \\
\text { tentang desa wisata kepada } \\
\text { masyarakat yang mayoritas }\end{array}$ & $\begin{array}{l}\text { Dilakukan pada pertemuan } \\
\text { kelompok masyarakat, }\end{array}$ \\
\hline
\end{tabular}

pengurus RT/RW, dan kelompok orang tua dan anak-anak. Kelompok sentra pemuda merupakan penggerak masyarakat lainnya dalam berkegiatan dan menjadi rekan kerja tim advokasi dalam memantau pelaksanaan kegiatan kepariwisataan. Kemudian, pengurus RT/RW serta pemerintah Desa Nglanggeran berperan dalam memberikan dukungan perizinan bagi pelaksanaan kegiatan di lingkungan desa. Terakhir, orangtua dan anak-anak. Mereka berperan aktif dalam kegiatankegiatan didalam kelompok sadar wisata.

Stakeholders tersebut berinteraksi agar dapat bekerja secara sinergis dalam proses pembentukan desa wisata dengan pembentukan lembaga sosial yang dapat memberdayakan masyarakat sekitar. Interaksi masyarakat terjadi sebagai kebutuhan manusia yang tinggal dalam lingkup wilayah yang sama. Kemudian dengan adanya kelompok sadar wisata interaksi masyarakat juga terjadi karena adanya dorongan untuk mencapai tujuan bersama.

Semangat dan tekad perjuangan pemuda ini mengembangkan kawasan wisata Gunung Api Purba berbuah manis. Tabel dibawah ini menunjukkan bahwa hasil prestasinya selama ini mendapatkan penghargaan. Beberapa penghargaan yang pernah disabet untuk dirinya sendiri serta untuk desa wisata Nglanggeran diantaranya: 


\begin{tabular}{|c|c|c|c|}
\hline & & $\begin{array}{l}\text { adalah petani, untuk bisa } \\
\text { mencoba mengikuti aktivitas } \\
\text { penunjang kegiatan wisata di } \\
\text { Desa Nglanggeran }\end{array}$ & $\begin{array}{l}\text { Tempat : Balai Dusun } \\
\text { masing-masing }\end{array}$ \\
\hline 2. & $\begin{array}{l}\text { Sosialisasi } \\
\text { Sapta Pesona }\end{array}$ & $\begin{array}{l}\text { Mengenalkan } \\
\text { memberikan penjelasan } \\
\text { tentang arti, nilai-nilai dan } \\
\text { juga implementasi sapta } \\
\text { pesona di masyarakat. }\end{array}$ & $\begin{array}{l}\text { Waktu : } 2 \text { Minggu sekali } \\
\text { untuk pemandu, } 35 \text { Hari } \\
\text { sekali untuk insane wisata } \\
\text { se-Desa Nglanggeran. } \\
\text { Tempat : Pendopo } \\
\text { Kalisong }\end{array}$ \\
\hline 3. & $\begin{array}{l}\text { Penyuluhan } \\
\text { kegiatan } \\
\text { perdagangan di } \\
\text { kawasan wisata }\end{array}$ & $\begin{array}{lr}\text { Sosialisasi } & \text { kepada } \\
\text { masyarakat } & \text { khususnya } \\
\text { kelompok pedagang untuk } \\
\text { melakukan } \\
\text { perdagangan dengan harga } \\
\text { sewajarnya saja walau } \\
\text { dikawasan wisata. }\end{array}$ & $\begin{array}{l}\text { Waktu : } 1 \text { Bulan sekali } \\
\text { Lokasi : kalisong dan } \\
\text { Kawasan Embung }\end{array}$ \\
\hline 4. & $\begin{array}{l}\text { Penyuluhan } \\
\text { Kesadaran } \\
\text { Sopan Santun } \\
\text { dan Service } \\
\text { Excelent } \\
\text { terhadap } \\
\text { pemandu }\end{array}$ & $\begin{array}{l}\text { Melakukan sosialisasi dan } \\
\text { pengarahan kepada semua } \\
\text { insane pariwisata khususnya } \\
\text { pemandu untuk dapat } \\
\text { berpenampilan sopan dan } \\
\text { memberikan pelayanan } \\
\text { optimal terhadap wisatawan }\end{array}$ & $\begin{array}{l}\text { Waktu : setiap hari ketika } \\
\text { briefing } \\
\text { Lokasi : Gunung Api } \\
\text { Purba dan Embung }\end{array}$ \\
\hline 5. & $\begin{array}{l}\text { Penyuluhan } \\
\text { Kesadaran } \\
\text { untuk Homestay }\end{array}$ & $\begin{array}{l}\text { Kegiatan sosialisasi kepada } \\
\text { masyarakat untuk bisa } \\
\text { bersedia digunakan sebagai } \\
\text { homestay. }\end{array}$ & $\begin{array}{l}\text { Waktu : 1 Bulan sekali } \\
\text { Lokasi : Pendopo } \\
\text { Kalisongo }\end{array}$ \\
\hline
\end{tabular}

Sumber: Arsip Pokdarwis Nglanggeran.

Tabel 2. Penghargaan yang telah diterima Pokdarwis Nglanggeran

\begin{tabular}{|c|l|l|}
\hline No & Jenis Penghargaan & \multicolumn{1}{|c|}{ Penjelasan/Deskripsi } \\
\hline 1. & $\begin{array}{l}\text { Piagam Karang } \\
\text { Taruna }\end{array}$ & $\begin{array}{l}\text { Dari Gubernur DIY sebagai Juara Pertama Penyelamat Lingkungan dalam } \\
\text { rangka Seleksi Kalpataru 2009 }\end{array}$ \\
\hline 2. & $\begin{array}{l}\text { Piagam } \\
\text { KarangTaruna }\end{array}$ & $\begin{array}{l}\text { Dari Kantor Pengendalian Dampak Lingkungan (KAPEDAL) sebagai } \\
\text { Juara pertama Lomba Lingkungan Hidup Tingkat Kabupaten } \\
\text { Gunungkidul tahun 2009 Kategori Penyelamat Lingkungan pada 21-23 } \\
\text { April 2009. }\end{array}$ \\
\hline 3. & Piagam Dinpar DIY & Juara harapan II Lomba Desa Wisata se-DIY Tahun 2009 \\
\hline 4. & Piagam Dinpar DIY & $\begin{array}{l}\text { Desa Nglanggeran sebagai desa Wisata dengan Keunikan Alam pada } \\
\text { Lomba Desa Wisata se-DIY pada Tahun 2009 }\end{array}$ \\
\hline 5. & $\begin{array}{l}\text { Piagam Bupati } \\
\text { Gunungkidul }\end{array}$ & $\begin{array}{l}\text { Karang Taruna Bukit Putra Mandiri Desa Nglanggeran sebagai juara } \\
\text { pertama lomba Penghijauan Swadaya Tingkat Kabupaten Gunungkidul } \\
\text { tahun 2001. }\end{array}$ \\
\hline 6. & $\begin{array}{l}\text { Piagam } \\
\text { Penghargaan Dinas } \\
\text { Sosial DIY }\end{array}$ & $\begin{array}{l}\text { Juara II Karang Taruna Berprestasi Tingkat Propinsi DIY Tahun 2009 dan } \\
\text { 2012 }\end{array}$ \\
\hline
\end{tabular}




\begin{tabular}{|c|l|l|}
\hline 7. & $\begin{array}{l}\text { Penghargaan } \\
\text { Blogdetik \& Telkom }\end{array}$ & $\begin{array}{l}\text { Salah satu pengelola Blog Gunung Api Purba Juara II Lomba Festival } \\
\text { Blog tahun 2010 tingkat Nasional dengan jumlah peserta 1.026 orang }\end{array}$ \\
\hline 8. & $\begin{array}{l}\text { Penghargaan } \\
\text { Kemenpora RI }\end{array}$ & $\begin{array}{l}\text { Salah satu pemuda pengelola Kawasan Ekowisata Gunung Api Purba } \\
\text { (Sugeng Handoko) menjadi pemuda pelopor bidang senibudaya dan } \\
\text { pariwisata tahun 2011 }\end{array}$ \\
\hline 9. & $\begin{array}{l}\text { Penghargaan } \\
\text { Kemenbudpar RI }\end{array}$ & $\begin{array}{l}\text { Pengelola Kawasan Ekowisata Gunung Api Purba sebagai finalis dalam } \\
\text { acara Cipta Award 2011 dalam pengelolaan Daya Tarik Wisata Alam } \\
\text { berwawasan Lingkungan }\end{array}$ \\
\hline 11. & $\begin{array}{l}\text { Penghargaan } \\
\text { Kementrian BUMN }\end{array}$ & $\begin{array}{l}\text { Salah satu kelompok pemuda pengelola wisata sebagai Social } \\
\text { Entrepreneur Lomba Mandiri Bersama Mandiri oleh Bank Mandiri Tahun } \\
\text { 2012 }\end{array}$ \\
\hline 12. & $\begin{array}{l}\text { Penghargaan } \\
\text { BKSDA DIY }\end{array}$ & $\begin{array}{l}\text { Salah satu anggota Pokdarwis (Sugeng Handoko) Juara I Kader } \\
\text { Konservasi Tingkat DIY Tahun 2013 }\end{array}$ \\
\hline 13. & $\begin{array}{l}\text { Penghargaan } \\
\text { Kemenhut RI }\end{array}$ & $\begin{array}{l}\text { Salah satu anggota Pokdarwis (Sugeng Handoko) Juara Harapan III Kader } \\
\text { Konservasi Tingkat Nasional Tahun 2013 }\end{array}$ \\
\hline 14. & $\begin{array}{l}\text { Penghargaan } \\
\text { Kemenparekraf RI }\end{array}$ & $\begin{array}{l}\text { Pokdarwis Desa Wisata Nglanggeran Juara II Pokdawis Berprestasi } \\
\text { Tingkat Nasional Tahun 2013 }\end{array}$ \\
\hline 15. & $\begin{array}{l}\text { Penghargaan } \\
\text { Kemenparekraf RI }\end{array}$ & $\begin{array}{l}\text { Pokdarwis Desa Wisata Nglanggeran Juara II Desa Penerima PNPM } \\
\text { Pariwisata Berprestasi Tingkat Nasional Tahun 2013 }\end{array}$ \\
\hline 16. & $\begin{array}{l}\text { Penghargaan } \\
\text { Kemenkokesra RI }\end{array}$ & $\begin{array}{l}\text { Salah satu anggota Pokdarwis (Sugeng Handoko) Juara II Lomba Menulis } \\
\text { 1001 Jejak PNPM Mandiri Tahun 2014 }\end{array}$ \\
\hline 17. & $\begin{array}{l}\text { Penghargaan } \\
\text { Kemenkokesra RI }\end{array}$ & $\begin{array}{l}\text { Salah satu anggota Pokdarwis (Sugeng Handoko) mendapat penghargaan } \\
\text { Kemenkokesra sebagai Pelaku PNPM Mandiri Terbaik Tahun 2014 }\end{array}$ \\
\hline
\end{tabular}
Sumber: Olah Data Arsip Pokdarwis Nglanggeran.

\section{KESIMPULAN}

Kewiralembagaan adalah atribut tindakan seorang aktor dan bukan atribut seorang aktor (Kusworo, 2015). Lembaga yang berinovatif dihasilkan oleh seorang wiralembagaan yang terus melakukan inovasi dan perubahan kearah yang lebih baik untuk menghasilkan lembaga yang dapat memberikan manfaat kepada masyarakat. Individu harus dapat memanfaatkannya untuk terhubung dengan struktur dan melakukan kerja wiralembaga atau inovasi institusi. Hal ini merupakan cara kewiralembagaan bisa berkontribusi terhadap pengembangan institusi yang inovatif.

Terdapat dua entitas dalam pembentukan kelompok sadar wisata di Desa Wisata Nglanggeran pertama adalah aktor/inisiator, yang kedua adalah struktur yakni peran dan partisipasi masyarakat dalam pengembangan desa wisata. Tindakan seorang lembagawan terbukti mampu memecahkan masalah sosial sehingga menginspirasi terbentuknya lembaga lain yang bergerak dalam perubahan tata hidup masyarakat.

\section{Keberhasilan Kelompok Sadar} Wisata Nglanggeran dalam melakukan pemberdayaan mayarakat tidak lepas dari peran seorang wiralembagawan. Sugeng Handoko seorang wiralembagawan berhasil mengajak masyarakat Desa Nglanggeran untuk aktif dalam pembentukan kelompok sadar wisata dan masyarakat dapat mengambil manfaat yang didapatkan dari kegiatan kepariwisataan. Faktor lain yang mendasari partisipasi masyarakat adalah karena adanya keinginan untuk menjaga dan melestarikan potensi alam yang dimiliki dan meningkatkan perekonomian masyarakat. Melalui pemberdayaan yang dilakukan oleh 
kelompok sadar wisata ini dihasilkan bahwa masyarakat sekitar merasakan manfaat yang positif.

\section{DAFTAR PUSTAKA}

Abdulsyani, 1994. Sosiologi (skematika, teori dan terapan), Penerbit: Bumi Aksara, Jakarta.

Basrowi dan Suwandi. 2008. Memahami Penelitian Kualitatif. Jakarta: Rineka Cipta.

BPS (Bandan Pusat Statistik)

Gunungkidul. 2013. Gunungkidul dalam angka 2013.

Damanik, Janianton. 2013. Pariwisata Indonesia Antara Peluang dan Tantangan. Yogyakarta: Pustaka Pelajar.

Desa Nglanggeran. 2007. Data Monografi Desa Nglanggeran Tahun 2007. Gunungkidul.

Desa Nglanggeran. 2013. Data

Kependudukan Desa Nglanggeran Tahun 2013.

Gunungkidul.

Klopf, Donald. W, 1985, Interacting In Groups: Theory and Practice, second edition, Colorado: Morton Publishing Company.

Kusworo, Hendrie Adji. 2000. Pengembangan Wisata Pedesaan Tepi Hutan Berbasis Kerakyatan, Pengusahaan Ekowisata. Yogyakarta: Fakultas Kehutanan UGM.

Kusworo, Hendrie Adji. 2009. Pariwisata untuk Kesejahteraan: Meninjau Ulang Kebijakan Pembangunan. Makalah Seminar Bulanan. Tanggal 28 Mei 2009. Yogyakarta: PSKP UGM Yogyakarta.

Kusworo, Hendrie Adji. 2015. Framing Poverty: An Instituonal
Entrepreneurship Approach to Poverty Alleviation through Tourism. Belanda: Groningen University.

Kusworo, Hendrie Adji. 2005. Pelatihan Sektor Ekonomi Strategis untuk Pembangunan Perdesaan: Aspek Kelembagaan dalam Pembangunan Perdesaan. Makalah.

Moleong, Lexy J. 2011. Metodologi Penelitian Kualitatif. Bandung: PT Remaja Rosdakarya Offset.

Nashir, Haedar. 2012. Memahami Strukturasi dalam Perspektif Sosiologi Giddens. Jurnal Sosiologi Reflektif, Volume 7, Nomor

Download.portalgaruda.org. (diakses tanggal 24 April 2015 Pukul 10.30 WIB).

Peraturan Menteri Kebudayaan dan Pariwisata RI No. P.M 04 / UM 001 / MKP / 2008 Tentang Sadar Wisata.

Peraturan Pemerintah Republik Indonesia Nomor 50 Tahun 2011 Tentang Rencana

Induk Pembangunan Kepariwisataan Nasional Tahun 2010 2025.

Peraturan Menteri Kebudayaan Dan Pariwisata Nomor: PM.26/UM.001/MKP/2010

Ritzer, George, 2010. Teori Sosiologi Modern. Jakarta: Kencana.

Soedjito, 1991, Transformasi Sosial Menuju Masyarakat Industri, Yogyakarta: PT Tiara Wacana.

Soekanto, Soerjono, 1997, Sosiologi Suatu Pengantar Cetakan ke-23, Jakarta: PT. Raja Grafindo Persada. 
Sugiyanto, 2002, Lembaga Sosial,

Yogyakarta: Global Pustaka

Utama.

Sugiyono, Prof. Dr. 2012. Metode

Penelitian Kuantitatif, Kualitatif,

dan $R \& D$. Bandung: CV Alfabeta.

Susyanti, Dewi Winarni. 2013. Potensi

Desa Melalui Pariwisata

Pedesaan. Jurnal Ekonomi dan

Bisnis, Vol 12, no. 1: 33-36.

Suwantoro, Gamal. 1997. Dasar-Dasar

Pariwisata. Yogyakarta: Andi.

Thoha, Miftah, 2002, Perilaku Organisasi, Konsep Dasar dan Aplikasinya, Jakarta: Raja Grafindo Persada.

Undang Undang No 10 Tahun 2009

Tentang Kepariwisataan.

Wheelan, Susan A, 1994, Group Prosesses, a developmental perspectif, Massachusetts: Allyn and Bacon.

\section{Internet :}

http://www.gunungapipurba.com/ diakses tanggal 3 Agustus 2015 Pukul 12.51 WIB.

http://nglanggeran-gunungkidul.info/ diakses tanggal 3 Agustus 2015

Pukul 12.49

WIB.

http://www.gunungkidulkab.go.id/home.p

$\underline{\mathrm{hp} \text { ?mode}=\text { content } \& \mathrm{id}=117}$

diakses tanggal

6 Agustus 2015 pukul 12.31 WIB.

http://www.gunungkidulkab.go.id/home.p

hp? mode $=$ content $\& i d=117$

diakses tanggal

6 Agustus 2015 Pukul 12.31 WIB.

http://www.indonesia.go.id/in/kementerian

/kementerian/13947-pariwisata-

indonesia-lampaui-pertumbuhan-

ekonomi diakses tanggal 4 Maret

2015 pukul 18.20 WIB. 